\title{
Genetically modified crops: the fastest adopted crop technology in the history of modern agriculture
}

\author{
Gurdev S Khush
}

\begin{abstract}
The major scientific advances of the last century featured the identification of the structure of DNA, the development of molecular biology and the technology to exploit these advances. These breakthroughs gave us new tools for crop improvement, including molecular marker-aided selection (MAS) and genetic modification (GM). MAS improves the efficiency of breeding programs, and GM allows us to accomplish breeding objectives not possible through conventional breeding approaches. MAS is not controversial and is now routinely used in crop improvement programs. However, the international debate about the application of genetic manipulation to crop improvement has slowed the adoption of GM crops in developing as well as in European countries. Since GM crops were first introduced to global agriculture in 1996, Clive James has published annual reports on the global status of commercialized GM crops as well as special reports on individual GM crops for The International Service for the Acquisition of Agri-biotech Applications (ISAAA). His $34^{\text {th }}$ report, Global Status of Commercialized Biotech/ GM crops: 2011 [1] is essential reading for those who are concerned about world food security.
\end{abstract}

Keywords: GM crops, Biotech crops, Agriculture, Crop improvement, Anti-GM zealots, ISAAA, Golden rice

\section{Discussion}

Clive James founded The International Service for the Acquisition of Agri-biotech Applications (ISAAA) more than 20 years ago in order to establish creative partnerships to facilitate the transfer of crop biotechnology applications from industrial countries, particularly from the private sector, for the benefit of small, resource-poor farmers in developing countries who represent a significant segment of the poorest people in the world. Subsequent to founding of ISAAA in 1990 it became clear that the lack of awareness by society of the potential of new, innovative genetically modified (GM) crops was a major constraint to their acceptance, exacerbated by extensive, well-resourced misinformation campaigns about GM crops by opponents of the technology.

James has made it his life's mission to put the information on GM crops in its proper perspective. To that effect, he travels around the world collecting information on biotech crops (as he calls them) and giving seminars. He has published annual reports on the global status of

Correspondence: gurdev@khush.org

Department of Plant Sciences, University of California, Davis, CA 95616, USA commercialized GM crops as well as special reports on individual GM crops. His publication, Global Status of Commercialized Biotech/ GM crops: 2011 [1], is his $34^{\text {th }}$ report on this subject.

In spite of the misinformation campaigns mentioned above there has been a steady increase in the land area planted to GM crops. The extensive data presented in Global Status of Commercialized Biotech/ GM crops: 2011 include the fact that GM crops were first planted in the United States in 1996 on an area of 1.7 million hectares. In 2011 GM crops were planted to 160 million hectares in 29 countries, of which 19 are developing countries. This means that $\mathrm{GM} /$ Biotech crops are the fastest adopted crop technology in the history of modern agriculture.

James cites a study which features the benefits accrued from the planting of GM crops. The value of increased crop production from planting GM/Biotech Crops between 1996 and 2010 was estimated at US $\$ 78$ billion. These plantings effected savings of 443,000,000 kg of pesticides, thereby contributing to environmental sustainability. In 2010 alone, GM/Biotech crops helped 
reduce $\mathrm{CO}_{2}$ emissions by 19 billion $\mathrm{kg}$ (equivalent to taking approximately nine million cars off the road). They helped conserve biodiversity by saving 91 million hectares of fragile lands from opening up for agriculture. In addition, they helped alleviate poverty by increasing incomes for 15 million small farmers who are among the poorest in the world.

In spite of these obvious benefits, there is unjustified opposition to the growing of GM crops. Numerous respected international scientific organizations have emphasized that GM crops and the foods prepared from them are as safe as foods prepared from conventional crops.

In October 2011, 41 leading Swedish Biological Scientists, in a strongly worded open letter to politicians and environmentalists, spoke out about the need to revise European Legislation to allow society to benefit from GM crops using science-based assessments of the technology. A contingent of scientists from the United Kingdom endorsed the Swedish petition. Dr. Felix M. Mbogi, a Kenyan national and a member of the African Biotechnology Forum, accused the European Union of 'hypocrisy and arrogance' and requested that development bodies within Europe allow African farmers to make full use of GM crops to boost yields and feed their populations.

A major roadblock in the rapid adoption of GM crops is the prolonged process of regulatory approval. There is an urgent need for appropriate science-based, cost-effective and time-effective regulatory systems that are responsible and rigorous but not onerous for small and poor developing countries. The need for such changes is illustrated by the case of 'Golden Rice'. It was developed in the public domain by the Potrykus group [2] in Switzerland to contribute to the reduction of vitamin A-malnutrition in ricedependent poor societies. Proof-of-concept for the engineered biosynthetic pathway was completed by February 1999. Product development beyond the basic research was not supported from the public domain. The project was rescued only because of support from the private sector. Problems related to intellectual property rights involved with the basic technology were solved within half a year. Product optimization by the private sector was donated to the Golden Rice Humanitarian Project. The putative impact of Golden Rice was calculated as up to 40, 000 lives saved per year for India alone. Despite substantial support for Golden Rice it will not reach the farmer before 2013. If Golden Rice were not a 'genetically engineered' (GE), variety development and registration would have been completed by 2002. This difference in time between traditional variety development and that of a GMO (genetically modified organism)-based variety of more than 10 years is due to nothing more than routine regulatory requirements. This difference translates, on the basis of the calculated impact of vitamin A deficiency, into far more than 400, 000 lives lost. This is especially difficult to accept when no risk to the environment or to the consumer can be claimed even hypothetically.

\section{Conclusions}

GM/Biotech crops are the fastest adopted crop technology in the history of modern agriculture. This means that, given a free choice, farmers worldwide have chosen to plant, and then replant, these crops. They have been able to exercise their choice, but anti-GM zealots, based primarily in Western Europe, have pressed for the adoption of GM-regulatory systems based on the concept of an 'extreme precautionary approach'. There is no scientific justification for this extremism which damages lives and welfare, especially of poor people. There is a moral imperative to make GM technology available for public good.

\section{Competing interests}

The author declares that he has no competing interests.

Received: 1 July 2012 Accepted: 26 July 2012

Published: 7 September 2012

\section{References}

1. James C: Global Status of Commercialized Biotech/ GM crops: 2011. ISAAA Brief No. 43. Ithaca: ISAAA; 2011.

2. Potrykus I: Lessons from the 'humanitarian Golden Rice' project: regulation prevents development of public good genetically engineered crop products. N Biotechnol 2010, 27:466-472.

doi:10.1186/2048-7010-1-14

Cite this article as: Khush: Genetically modified crops: the fastest adopted crop technology in the history of modern agriculture. Agriculture \& Food Security 2012 1:14.

\section{Submit your next manuscript to BioMed Central and take full advantage of:}

- Convenient online submission

- Thorough peer review

- No space constraints or color figure charges

- Immediate publication on acceptance

- Inclusion in PubMed, CAS, Scopus and Google Scholar

- Research which is freely available for redistribution

Submit your manuscript at www.biomedcentral.com/submit
C Biomed Central 